DOI 10.18413/2312-3044-2018-5-2-233-236

\title{
NOTES ON THE SECOND BELGOROD SUMMER SCHOOL IN BYZANTINE STUDIES
}

\author{
Evgenii I. Miroshnichenko \\ St. Petersburg State University \\ Universitetskaia emb. 7/9, St. Petersburg, 199034, Russia \\ E-mail: miroshnichenkoeu@gmail.com
}

\begin{abstract}
The author gives an overview of the Second Belgorod Summer School in Byzantine Studies which was held at Belgorod National Research University in August 2018.
\end{abstract}

Keywords: Byzantine Studies, summer school, Belgorod, 2018.

Copyright: (C) 2018 Miroshnichenko. This is an open-access publication distributed under the terms of the Creative Commons Attribution License, which permits unrestricted use, distribution, and reproduction in any medium, provided the original authors and source, the Tractus Aevorum journal, are credited.

Correspondence to: Evgenii Miroshnichenko, St. Petersburg State University, Institute of History. Universitetskaia emb. 7/9, St. Petersburg, 199034, Russia. E-mail: miroshnichenkoeu@gmail.com

\section{II БЕАГОРОДСКАЯ АЕТНЯЯ ШКОАА ПО ВИЗАНТОАОГИИ}

\section{Е. И. Мирошниченко}

Санкт-Петербургский государственный университет 199034, Университетская наб. 7/9, Санкт-Петербург, Россия

E-mail: miroshnichenkoeu@gmail.com

Аннотация. В работе представлен обзор II цетней школы по византологии, которая состоянась на базе Белгородского государственного национального исследовательского университета в августе 2018 г.

Ключевые слова: византология, цетняя школа, Белгород, 2018.

The Second Summer School in Byzantine Studies took place in Belgorod in August 2018. Without a doubt, the event can be called unique as the first such school to be held in this country. Neither the first summer 
school on Byzantine Studies, which was held here last year, nor the Moscow school, which took place in October 2015 in Voronovo at the Higher School of Economics, had the current format. Previous events were held in a conference format, with most of the reports and presentations made by the participants themselves. The present school was different. The participants acted as student participants in seminars and roundtables, listening to lectures of specially invited quests: Mikhail Gratsianskii (Moscow), Pavel Kuzenkov (Moscow), Nikolai Bolgov (Belgorod) and Nikolai Bystritskii (Moscow). This format contributes to the creation of what we like to call the academic tradition: the older generation of Byzantinists shares their experience with younger researchers. It would be difficult to find a better site for this opportunity than Titovka, a cozy and quiet place in a natural setting. Everything here contributes to research work. Attention should be paid to the fact that communication between different generations of researchers did not only take place during strictly measured hours of lectures, seminars, and roundtables, but also during evening leisure hours and by the fire in a relaxed atmosphere.

Half of the school participants came to Titovka from Belgorod, while representatives from other Russian cities were distributed as follows: one participant from Moscow, one from St. Petersburg, two from Ekaterinburg, one from Omsk, and one from Tula. There is an obvious increase in territorial coverage compared to the previous school.

On Tuesday, August 14, participants gathered at the BelSU facility in Titovka. During the day, introduction of the participants took place, during which everyone shared their views on the history of Byzantium and explained how they came to Byzantine studies. Most of the participants are specialists in the early Byzantine period. In addition, the school brought together experts from the most diverse areas: historians, archaeologists, philologists, and even philosophers. On the same day, Gratsianskii, Kuzenkov, and Bolgov moderated a roundtable entitled "Byzantium and us" to discuss the question of what Byzantium means for us as researchers.

The next day, August 15, was very intense. In the morning, Bolgov and Vladimir Kirillov presented on the topic, "Early Byzantium in the Archaeological Research of BelSU in the Crimea," showcasing interactive maps of the excavations of early Byzantine objects in the Crimea. Particular attention was paid to the fortress of Kytaia, where for many years BelSU has conducted archaeological research. This was followed by a presentation from Bolgov and Maria Rudneva on the Byzantine regions of Armenia, where Byzantinists of Belgorod went last year (and are going this year) to participate in a summer school. The presentation showed various architectural objects, in particular from the ancient temples of the Byzantine period. Kuzenkov then gave a lecture on "Peripheral Regions of the Eastern Roman Empire in the Fifth through Eighth Centuries," while Gratsianskii lectured on the Economic Situation in Regions of the Roman Empire in the Fourth through Sixth Centuries." In his lecture, Kuzenkov spoke in detail 
about the political situation on the periphery of the Byzantine Empire from Theodosius to the Arab conquests. In particular, he raised an interesting question about the attitude of the local population (Copts, Syrians) to royal power and Constantinople. This question is especially intriguing in the context of the emergence of various heresies. For his part, Gratsianskii studied the same regions economically, drawing attention to specific issues of financial support for the empire.

After lunch, Gratsianskii ran a seminar on "Regional Balance of Power in the Roman Empire in the Fourth through Sixth Centuries: West vs. East" based on some interesting data. He reviewed the interaction between the Western and Eastern Empires and the reasons for the fall of the Western Empire and the flourishing of the Eastern Empire under Justinian in connection with the regions.

The day closed with Bolgov's "Early Byzantine Medical Tradition" seminar, which reviewed the most important historical sources on this topic, and investigated the tradition from Galen. This question is also important in connection with philosophical studies of early Byzantine thought that have been popular recently.

The next day (August 16) began with a lecture by Kuzenkov on "The Financial System of the Roman Empire in the Fourth through Tenth Centuries," which was continued and supplemented by Gratsianskii's seminar on "Incomes and Prices in the Roman Empire in the Sixth through Tenth Centuries." The audience showed significant interest in this topic because it clearly demonstrated the prices of certain goods, as well as the level of incomes of certain social groups based on historical data. Gratsianskii drew the attention of the participants to the important and useful work by Ostrogorskii in this respect, as well as to a monograph by Morrison and Chaney on the same topic. Then Kuzenkov and Gratsianskii held a seminar on the "Book of the Perfect," the famous tenth-century legislative document. Two lectures on the Justinian era were given after lunch, one on political theory (Kuzenkov, "The Political Theory of Justinian the Great Period"), and the other on the interaction of politics and theology (Gratsianskii, "Theology and Politics in the Roman Empire in the Fifth through Sixth Centuries.")

The day (August 17) broached problems related to the history of early Byzantine culture. In the morning, seminars addressed the history of the Alexandrian school of philosophy (Bolgov, Rudneva) and early Byzantine secular epistolography (Bolgov, Evgenii Miroshnichenko). The first seminar considered the problems of interaction between the Neoplatonic and Christian traditions in works by such thinkers as Ammonius, Olympiodor, Philopon. The presenters noted the important influence of Aristotelian thought on the early Byzantine theologians of Alexandria. The second seminar discussed the specificity of the early Byzantine epistolografy and its representatives, such as Aeneas and Prokopius of Gaza and Synesius of Cyrene. After lunch, Kuzenkov ran a seminar on "Novellae Constitutiones 
about Imperial Power," while Bolgov spoke about the early Byzantine epic (the topic has been hardly studied in Russia) and its representatives: Corippus, Priscian, John of Gaza, Nonnus, Triphiodorus, and Christodorus of Coptos.

The last day of school (August 18) featured two seminars. One seminar by Bolgov explored the topic of "John Malalas and the Medievalization of Historical Knowledge in Early Byzantium." The second seminar by Bystritskii related modern information resources on the history of Byzantium. The event closed with a summation of the school and a closing ceremony, at which school participants received certificates.

Translated from Russian by Alexander M. Amatov

\section{About the author}

Evgenii Miroshnichenko is a PhD candidate in the Institute of History at St. Petersburg State University. 